\title{
"Earnings management and seasoned equity offerings: evidence from Taiwan started Go Incubation Board for Startup and Acceleration firms"
}

\begin{tabular}{|c|c|}
\hline AUTHORS & $\begin{array}{l}\text { An-An Chiu } \\
\text { Shaio Yan Huang } \\
\text { Ling-Na Chen iD https://orcid.org/0000-0002-3542-6998 } \\
\text { Wei-Hua Lin }\end{array}$ \\
\hline ARTICLE INFO & $\begin{array}{l}\text { An-An Chiu, Shaio Yan Huang, Ling-Na Chen and Wei-Hua Lin (2020). Earnings } \\
\text { management and seasoned equity offerings: evidence from Taiwan started Go } \\
\text { Incubation Board for Startup and Acceleration firms. Investment Management and } \\
\text { Financial Innovations, 17(2), 183-197. doi:10.21511/imfi.17(2).2020.15 }\end{array}$ \\
\hline DOI & http://dx.doi.org/10.21511/imfi.17(2).2020.15 \\
\hline RELEASED ON & Tuesday, 16 June 2020 \\
\hline RECEIVED ON & Sunday, 16 February 2020 \\
\hline ACCEPTED ON & Wednesday, 27 May 2020 \\
\hline LICENSE & $\begin{array}{l}(\mathrm{cc}) \mathrm{EY} \\
\text { This work is licensed under a Creative Commons Attribution } 4.0 \text { International } \\
\text { License }\end{array}$ \\
\hline JOURNAL & "Investment Management and Financial Innovations" \\
\hline ISSN PRINT & $1810-4967$ \\
\hline ISSN ONLINE & $1812-9358$ \\
\hline PUBLISHER & LLC "Consulting Publishing Company "Business Perspectives" \\
\hline FOUNDER & LLC "Consulting Publishing Company "Business Perspectives" \\
\hline
\end{tabular}

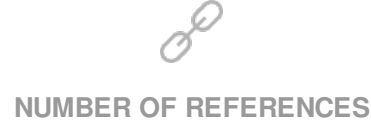

36
NUMBER OF FIGURES

0
=:-

NUMBER OF TABLES

9

(C) The author(s) 2023. This publication is an open access article. 


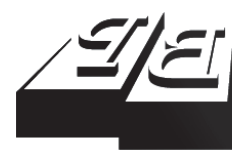

\section{BUSINESS PERSPECTIVES}

LLC "CPC "Business Perspectives" Hryhorii Skovoroda lane, 10, Sumy, 40022, Ukraine www.businessperspectives.org

Received on: $16^{\text {th }}$ of February, 2020 Accepted on: $27^{\text {th }}$ of May, 2020 Published on: $16^{\text {th }}$ of June, 2020

(c) An-An Chiu, Shaio Yan Huang, LingNa Chen, Wei-Hua Lin, 2020

An-An Chiu, Associate Professor, College of Business, Department of International Business, Feng Chia University, Taiwan.

Shaio Yan Huang, Professor, College of Management, Department of Accounting and Information Technology, National Chung Cheng University, Taiwan

Ling-Na Chen, Ph.D. Candidate, College of Management, Department of Accounting and Information Technology, National Chung Cheng University, Taiwan. (Corresponding author)

Wei-Hua Lin, Master, College of Management, Department of Accounting and Information Technology, National Chung Cheng University, Taiwan
An-An Chiu (Taiwan), Shaio Yan Huang (Taiwan), Ling-Na Chen (Taiwan), Wei-Hua Lin (Taiwan)

\section{EARNINGS MANAGEMENT} AND SEASONED EQUITY OFFERINGS: EVIDENCE FROM TAIWAN STARTED GO INCUBATION
BOARD FOR STARTUP
AND ACCELERATION FIRMS

\section{Abstract}

Although a large body of empirical research focuses on listed companies, less is done regarding small and medium enterprises. Under the authorities' support, Taipei Exchange (TPEx) started Go Incubation Board for Startup and Acceleration Firms (GISA) in January 2014. This research yields insight into earnings management activities around seasoned equity offerings (SEO) based on GISA firms in Taiwan and the effectiveness of external corporate governance. Data for the study come from the GISA Market Observation Post System of TPEx and Taiwan Economic Journal. The results reveal that GISA firms with the incentives of raising funds are prone to upward accrual-based earnings management during SEO to avoid long-term negative consequences. Especially, firms with paid-in capital more than TWD (NT\$) 30 million, higher fundraising amounts, or smaller-sized firms, tend to increase discretionary accruals. Finally, Certified Public Accountants (CPAs) and Big 4 accounting firms effectively serve as external corporate governance on mitigating earnings management. This study makes some contributions to GISA literature. First, expands the prior research, the different earnings management level before and listed on GISA, to the firms listed on GISA. Second, link up the relationship between the SEO and earnings management of GISA in Taiwan. Finally, it provides several contributions to regulators, for instance, the effectiveness of the counseling system provided by CPAs or Big 4 accounting firms. Also, the CPAs and Big 4 accounting firms serve as supervisors on corporate governance.

\section{Keywords}

earnings management, seasoned equity offerings, accrual-based earnings management, discretionary accruals, corporate governance

\section{JEL Classification G34, M41, M48}

\section{INTRODUCTION}

According to the White Paper on Small and Medium Enterprises in 2016 published by the Ministry of Economic Affairs, enterprises' paidin capital less than NT\$ 50 million takes up nearly $98 \%$, which equals $1,383,981$ firms of total enterprises in Taiwan. Only the remaining $1.4 \%$ and $0.6 \%$ of companies meet the criteria of paid-in capital in emerging listing and over-the-counter listing. Therefore, it is hard for small and medium enterprises (SMEs) to raise funds from the capital market.

To simplify the securities issuance procedures of the start-up company and improve the information transparency, the US set up Jumpstart Our Business Startups Act (JOBS Act) in 2012. Two years later, in 2014, the Taipei Exchange (TPEx) have modeled Go Incubation Board for Startup and Acceleration Firms (GISA) after US JOBS Act Title III Crowdfunding, providing the SMEs with innovation, creativity, and 
paid-in capital under NT\$ 50 million, options to raise funds on the capital market. In other words, the GISA is an equity-based crowdfunding portal without the function of equity transactions. The GISA portal can provide a bridge between companies and investors to increase information transparency and financial report reliability. Until the end of May 2017, 77 enterprises were listed on the GISA and effectively raised nearly NT\$245 million.

Prior literature suggests the relationship between listed initial public offering (IPO) or seasoned equity offerings (SEO) companies and earnings management on the US stock market (Cohen \& Zarowin, 2010; Fan, 2007). However, the earnings management activities around SEO and external corporate governance based on GISA firms in Taiwan have received little attention. Also, there is little difference in set-up purposes between the GISA board and the stock market. Following the obligations, the GISA companies are required to disclose the information on the GISA Market Observation Post System. Thus, GISA firms that aim to raise funds from the capital market or to list on the mainboard in the future may have the incentives to conduct earnings management. However, most of SMEs in Taiwan do not meet the criteria to list on TPEx or TWSE. If these SMEs listed on GISA and have the incentives to SEO, they may make efforts to attract more outsiders' capital investment. One of the methods to raise more funds or be listed on the mainboard is to conduct earnings management. The research mainly focuses on the companies listed on the GISA board. This study aims to discuss whether or not SEO firms have more earnings manipulation for those GISA firms than non-SEO firms. Furthermore, it compares the pre- and post- earnings performance during the next SEO period. Finally, it is examined whether the certified public accountants (CPAs) and Big 4 accounting firms can effectively lighten the earnings manipulation behavior.

Overall, this study makes several contributions to the GISA and earnings management literature. First, GISA firms conducting SEO have higher incentives to conduct discretionary accruals than non-SEO firms. Next, outsiders cannot effectively lessen or heighten earnings management behaviors from management. Besides, this paper expands the prior research of earnings management that firms have different earnings management level before and after listing on GISA in an emerging economy. Finally, this paper contributes to regulators that the CPAs and Big 4 accounting firms serve as supervisors on corporate governance. The results imply the effectiveness of the counseling system provided by CPAs or accounting firms.

The remaining part of this paper is organized as follows. Section 1 reviews the relevant prior research and introduces the hypotheses. Furthermore, this paper presents the research model and discusses the research methodology in section 2 , and the experimental results are subsequently analyzed in section 3. Last section presents the conclusion of the study and provides crucial suggestions and future implications.

\section{LITERATURE REVIEW}

This paper will review the literature concerning the GISA, earnings management, and external corporate governance. The first sub-section gives an overview of GISA in Taiwan, including the establishment purpose, the motivations on GISA firms, and its current situation. The second sub-section reviews the literature on earnings management, focusing on IPO and SEO. The last sub-section analyzes prior research related to the effect of external corporate governance on earnings management.

\subsection{Go Incubation Board for Startup and Acceleration Firms (GISA)}

According to the White Paper on Small and Medium Enterprises in Taiwan published by the Ministry of Economic Affairs in 2016, the number of SMEs with paid-in capital below NT\$ 50 million is apart from the existing emerging established stock market and mainboard (previously called as OTC) listing for public offerings. Table 1 shows that the government hoping the multi-level capital markets will pave the way for economic and business development in Taiwan. 
Table 1. Comparison of capital markets in Taiwan

\begin{tabular}{|c|c|c|c|c|}
\hline \multirow[b]{2}{*}{ Type } & \multicolumn{2}{|c|}{ Non-public offering } & \multicolumn{2}{|c|}{ Public offering } \\
\hline & Gofunding zone & GISA & Emerging stock board & $\begin{array}{l}\text { Over-the-counter } \\
\text { listing }\end{array}$ \\
\hline Establishment & Aug $19^{\text {th }}, 2013$ & $\operatorname{Jan} 3^{\text {rd }}, 2014$ & $\operatorname{Jan} 2002$ & Nov 1995 \\
\hline Business scale & $\begin{array}{l}\text { For micro-company, } \\
\text { studio, or individual }\end{array}$ & $\begin{array}{l}\text { For a small-sized } \\
\text { innovative company }\end{array}$ & $\begin{array}{l}\text { For small and medium enterprises } \\
\text { before over-the-counter listing }\end{array}$ & $\begin{array}{l}\text { For small and medium } \\
\text { enterprises }\end{array}$ \\
\hline
\end{tabular}

\subsection{Earnings management}

\subsubsection{Incentives for earnings management}

Financial reports are one of the ways of telling stakeholders about the underlying firm's economic performance. Prior literature presents significant evidence on earnings management. Healy and Wahlen (1999) considers the earnings management to be managers' discretion in their financial reporting decision to either mislead the real economic performance or influence the contractual results based on accounting numbers. Schipper (1989) uses traditional accruals measurement by connecting the accrual items to financial performance and finds that companies' performance-matched discretionary accrual is an alternative measurement in earnings management. However, existing research recognizes the critical role of external corporate governors in constraining earnings management. Bédard, Chtourou, and Courteau (2004) show a negative relationship between aggressive earnings management and the expertise of audit committee members. Chen, Lin, and Zhou (2005) also reach a similar conclusion using the samples from Taiwan Economic Journal database from 1999 to 2002 and find that Big 5 auditors are related to fewer earnings management in IPO year in Taiwan.

Based on the agency theory, Chung, Firth, and Kim (2002) develop executives reporting incentives to manage earnings in the book titled "Positive Accounting Theory". Companies may offer different contracts to insiders or outsiders, such as compensation plan or debt covenant, to alleviate agency conflicts and reduce agency problems. However, the measurement criteria of these contracts are based on the accounting information, which will easily be altered once the managements are under the compensation of debt pressure. Moreover, the bigger the corporation, the higher the political pressure they face. In order not to raise politically sensitive, the management may have a higher propensity to choose the income-decreasing accounting policy. The earnings management motivations are derived from the following hypotheses.

The bigger operating size or better profitability, the more political pressure companies should bear. The pressure on the company makes the managers lower the earnings to get less attention from the government and supervisors. The prior literature also indicates that the government or overseers keep eyes on the large companies more than the small ones. The big corporations will downward earnings to lessen unnecessary political costs (Kothari, Leone, \& Wasley, 2005). Sheng (1997) also proves that large companies with higher earnings performance will cause attention from society. Gunny (2005) examines the consequences of real earnings management and finds its significant negative impact on future operating performance. The IPO companies tend to window-dress the financial statements before applying and listing on the board. Chin, Lin, and Huang (2000) approve that in SEO and previous SEO period, managers are prone to upward discretionary accruals. Teoh, Wong, and Rao (1998) find abnormal accruals during the years of IPOs. DuCharme, Malatesta, and Sefcik (2001) use the Modified Jones Model to estimated accruals and compare the stock return after IPO. The results show that the pre-IPO abnormal accruals are positively related to firm value and negatively related to abnormal accruals after the offering date.

Teoh, Welch, and Wong (1998) prove that capital market motivations are the most significant incentives for managers to manipulate earnings. In Taiwan, enlarged companies' operation capital is the main reason for companies to raise capital. Teoh et al. (1998), and Rangan (1998) find that managers are prone to significantly upward the discretional accruals, particularly in that capital raising period. The authors also reveal that the 
degree of accrual earnings manipulation will be larger for debt repayment than plant expansion. Several kinds of literature investigate the joint decision of discretionary accruals and asset dispose of SEO. The authors find that in SEO and previous SEO period, the companies have higher discretionary accruals. Besides, the results show that discretionary accruals and assets disposal is a complementary correlation in SEO and pre-SEO period and prove that managements consider two methods jointly.

\subsubsection{Accrual earnings management}

According to the prior research, the accruals can be divided into discretionary and non-discretionary. Discretionary accruals mean that the managers adjust cash flow from an opportunity set of GAAP. Non-discretionary shows the manager adjust cash flows authorized by accounting standard-setting bodies. Owing to the information asymmetry between management and stakeholders, the manipulate behaviors are hard to detect. Enterprises often use discretionary accruals. To sum up, discretionary accrual is a good index of earnings management. Chin et al. (2000) put forward the method using total accruals, including both discretionary and non-discretionary components, to measure earnings management. Cohen and Zarowin (2010) estimated by change in total accruals. Healy (1985) indicates that the residual from a regression of total accruals on change in sales and property, plant, and equipment. Further, Healy (1985) proposes the Modified Jones Model, which is the residual from a regression of total accruals on change in sales and property, plant, and equipment, where revenue is adjusted for changes in receivable in the event during the period. DeAngelo (1986) calculates residual from the regression of non-cash current assets as fewer liabilities on lagged levels of these balances and adjusted for the increase in revenues, expenses and property, plant, and equipment.

\subsection{External corporate governance in mitigating earnings management}

Corporate governance is a system used to direct and supervise an organization's performance. Dechow, Sloan, and Sweeney (1996) find that through corporate governance, internal control mechanisms not only can improve the reliability of the financial statements but also mitigate the earnings manipulation.

GISA is different from Main Board without setting corporate governance regulation. However, during the public integrative counselling step, the counselor will provide a standard internal control system for the GISA firms as an example. With sound corporate governance mechanisms, companies can work more efficiently to improve information transparency and reduce the possibility of accounting fraud.

Prior literature proves that financial statements audited by CPAs can lessen the information asymmetry and protect stockholders' equity (Fama \& Jensen, 1983). CPA with high auditing quality can inhibit earnings management level due to the management's fear of disclosure (Dechow et al., 1996). Financial reports audited by CPAs can enhance credibility. However, according to GISA regulation, CPAs auditing is not a mandatory item if firms' paid-in capital is less than NT\$ 30 million.

The evidence shows that the US companies with Big 4 auditors have higher earnings quality than the firms with non-Big 4 auditors (Teoh \& Wong, 1993). Kim, Chung, and Firth (2003) find that Big 6 auditors are more effective than nonBig 6 auditors in detecting opportunistic earnings management. Francis and Wang (2008) indicate that only for firms with the well-known international Big 4 auditors, the earnings quality is better, and investor protection becomes stronger. Thus, Big 4 auditors enforce higher reporting quality. These findings suggest that better quality of audit quality is related to effective monitoring, limiting accrual-based earnings management.

Brickley, Coles, and Terry (1994) prove that when the percentage of outsiders increases, the discretionary accruals would decrease. Later, Peasnell, Pope, and Young (2005) also indicate the negative relationship between outsiders' proportion and managers' income-increasing abnormal accruals. On the other hand, Shivakumar (2000) finds that to influence investors' decisions and have a better offering price, and the management tends to manipulate earnings before SEO. That 
is to say, have a better offering price or receive sufficient funds from outsiders' investors (higher outsiders' subscription rate), the SEO firms tend to manage earnings around SEOs; and the better the earnings performance, the higher possibility to receive more investment amount. Most of the prior literature verifies that the external corporate governors, such as certified public accountants and Big 4, alleviate the agency problems among management, stockholders, and stakeholders (OECD). As for outsiders' subscription rates, there are mixed results in the literature. In general, the better external corporate governance, the better effectiveness of mitigating earnings management behavior.

\subsection{Hypotheses development}

In the past, almost $98 \%$ of the companies in Taiwan without sufficient paid-in capital have difficulty in fundraising from the capital market. Now, there is a new stage, GISA, for SMEs to raise funds from the capital market, enlarge business scale and publicity, and even list on the stock market in the future.

Based on prior research, Dechow, Sloan, and Sweeney (1995) deliberate earnings management behaviors from the viewpoint of incentives. They find that capital raising incentives are the most significant ones affecting earnings management. The majority of prior earnings management literature focuses on earnings manipulation through the discretionary accruals items (K. Chen, Z. Chen, and Wei, 2009; Healy, 1985). Thus, the SEO firms with earnings management incentives may conduct accruals-based earnings management Cohen and Zarowin (2010) and Healy and Wahlen (1999) lead a similar conclusion that, on average, SEO firms have upward abnormal accruals around the SEO year. Chin et al. (2000) document that in SEO and previous SEO period, managers are prone to use discretionary accruals to manage earnings upward, which prove the positive relationship between SEO and earnings management in the listed company.

According to registrations on GISA, one of the missions that the registered GISA firms should complete is to reach the capital raising target. However, the GISA firms listed not only for the channel of fundraising but also looking forward to listing on the mainboard and getting sufficient resources from the capital market in the future. Thus, this paper expects that GISA firms with the financial needs share the same characteristic as the mainboard listed companies. If the GISA firms have the incentives to raise funds or list on the mainboard in the future, the SEO firms will have a higher level of earnings management behaviors than non-SEO firms. Therefore, SEO firms with fundraising needs are likely to have earnings management behavior. Thus, the first hypothesis is formulated as follows:

H1: After the GISA has been listed, the company conducting SEO has a higher level of earnings management than non-SEO.

Further, this paper predicts that the earnings management behavior will alleviate if financial statements audited by CPAs, Big 4 accounting firms, and outsiders. Prior literature proves that auditors may influence earnings management level due to in-depth knowledge of accounting and financial reporting (Teoh et al., 1998). Evidence shows that Big 4 auditors deliver higher quality audits than non-Big 4 auditors (Cohen \& Zarowin, 2010; Francis \& Wang, 2008; Kim et al., 2003). As for outsiders' subscription rates, there are different points of view. Brickley, Coles, and Terry (1994) and Peasnell, Pope, and Young (2005) indicate the negative relationship between outsiders' proportion and upward abnormal accruals. However, Shivakumar (2000) finds that to have a better offering price or receive sufficient funds from outsiders' investors, and the management tends to conduct earnings management around SEOs. According to these empirical results, the second hypothesis is set as follows:

H2a: For SEO firms listed on GISA, the level of earnings management is lower when audited by the CPAs.

H2b: For SEO firms listed on GISA, earnings management level is lower when audited by Big 4 accounting firms.

H2c: For SEO firms listed on GISA, there is an association between the earnings management level and outsiders' subscription rate. 


\section{METHODOLOGY}

\subsection{Measurement \\ of earnings management}

The common state of the approaches to earnings quality measures uses discretionary accruals (DA) as the proxy of earnings quality following prior studies (Yuk \& Leem, 2017; Dechow, Ge, \& Schrand, 2010). To capture the extent of the earnings management of SEO firms, this paper estimates the following models by prior research. This research refers to the Modified Jones Model by Roychowdhury (2006). Previous studies (Healy, 1985; DeAngelo, 1986) use total accruals as a proxy for earnings management while Jones (1991), Dechow, Sloan, and Sweeney (1995) use discretionary accruals as a measure of earnings management. The reason to exclude non-discretionary accruals is that they are used to reflect business conditions that the managers cannot control. This paper considers a modified version of the Jones Model in the empirical analysis. In the modified model, non-discretionary accruals are estimated during the event period. The advantage of Modified Jones Model is to eliminate the conjectured tendency in measuring discretionary accruals with an error when managers use the discretion right for revenues:

$$
\begin{aligned}
& T A_{i, t}=\alpha_{1} \cdot\left(\frac{1}{\operatorname{ASSETS}_{i, t-1}}\right)+ \\
& +\alpha_{2} \cdot\left(\frac{\Delta \operatorname{SALES}_{i, t}-\Delta R E C_{i, t}}{A S S E T S_{i, t-1}}\right)+ \\
& +\alpha_{3} \cdot\left(\frac{P P E_{I, T}}{\operatorname{ASSETS}_{i, t-1}}\right)+\alpha_{4} \cdot \operatorname{ROA}_{I, T}+\varepsilon_{i, t} .
\end{aligned}
$$$$
N D A_{i, t}=\hat{\alpha}_{1} \cdot\left(\frac{1}{A S S E T S_{i, t-1}}\right)+
$$$$
+\hat{\alpha}_{2} \cdot\left(\frac{\Delta S A L E S_{i, t}-\Delta R E C_{i, t}}{A S S E T S_{i, t-1}}\right)+
$$$$
+\hat{\alpha}_{3} \cdot\left(\frac{P P E_{I, T}}{\operatorname{ASSETS}_{i, t-1}}\right)+\hat{\alpha}_{4} \cdot R O A_{I, T} .
$$

$$
D A_{i, t}=T A_{i, t}-N D A_{i, t} .
$$

where $T A_{i, t}$ is the total accruals in year $t$ for firm $i$, equals to $\left(N I_{i t}-C F O_{i t}\right) /\left(\right.$ ASSETS $\left._{i, t-1}\right)$, $N D A_{i, t}$ is the non-discretionary accruals for company $i$ in year $t, D A_{i, t}$ is the difference of total discretionary accruals and non-discretionary accruals for company $i$ in year $t, A S S E T S_{i, t-1}$ is the total assets for the company $i$ in year $t-1$, $\triangle S A L E S_{i, t}$ is the difference of net sales revenue for company $i$ in year $t$ and $t-1, \triangle R E C_{i, t}$ is the difference of account receivables for company $i$ in year $t$ and $t-1, P P E_{i, t}$ is the gross amount of fixed assets for company $i$ in year $t, R O A_{i, t}$ is the return on assets for company $i$ in year $t$.

\subsection{Research models}

This paper investigates the relationship between SEO and earnings management for regression (4). Further, it examines the supervision of CPAs and Big 4 accounting firms on earnings management using the regression equations (5), and (6). Finally, it inspects the ability of CPAs, Big 4 accounting firms, and outsiders in mitigating earnings management, especially in SEOs, using the regression equations (7), (8), and (9):

$$
\begin{aligned}
& D A_{i, t}=\alpha_{0}+\alpha_{1} S E O_{i, t}+\alpha_{2} \text { PIC }_{i, t}+ \\
& +\alpha_{3} \operatorname{SIZE}_{i, t}+\alpha_{4} F Y_{i, t}+\alpha_{5} \operatorname{GROW}_{i, t}+ \\
& +\alpha_{6} L E V_{i, t}+\alpha_{7} I N D F E_{i, t}+\alpha_{8} Y_{R F E_{i, t}}+\varepsilon_{i, t} .
\end{aligned}
$$

$$
\begin{aligned}
& D A_{i, t}=\alpha_{0}+\alpha_{1} S E O_{i, t}+\alpha_{2} P I C_{i, t}+\alpha_{3} C P A_{i, t}+ \\
& +\alpha_{4} \operatorname{SIZE}_{i, t}+\alpha_{5} F Y_{i, t}+\alpha_{6} \text { GROW }_{i, t}+ \\
& +\alpha_{7} L E V_{i, t}+\alpha_{8} I N D F E_{i, t}+\alpha_{9} Y R F E_{i, t}+\varepsilon_{i, t} . \\
& D A_{i, t}=\alpha_{0}+\alpha_{1} S E O_{i, t}+\alpha_{2} P I C_{i, t}+\alpha_{3} B I G A_{i, t}+ \\
& +\alpha_{4} \operatorname{SIZE}_{i, t}+\alpha_{5} F_{i, t}+\alpha_{6} \mathrm{GROW}_{i, t}+ \\
& +\alpha_{7} L E V_{i, t}+\alpha_{8} I N D F E_{i, t}+\alpha_{9} Y_{R F E_{i, t}}+\varepsilon_{i, t} \text {. } \\
& D A_{i, t}=\alpha_{0}+\alpha_{1} C P A_{i, t}+\alpha_{2} A M T_{i, t}+ \\
& +\alpha_{3} C I N V_{i, t}+\alpha_{4} \text { IIN }_{i, t}+\alpha_{5} F Y_{i, t}+ \\
& +\alpha_{6} \text { LOSS }_{i, t}+\alpha_{7} \text { GROW }_{i, t}+ \\
& +\alpha_{8} I N D F E_{i, t}+\alpha_{9} Y_{R F E_{i, t}}+\varepsilon_{i, t} \text {. }
\end{aligned}
$$




$$
\begin{aligned}
& D A_{i, t}=\alpha_{0}+\alpha_{1} \text { IIG }_{i, t}+\alpha_{2} A M T_{i, t}+ \\
& +\alpha_{3} \text { IINV }_{i, t}+\alpha_{4} \text { FIN }_{i, t}+\alpha_{5} F Y_{i, t}+ \\
& +\alpha_{6} \text { LOSS }_{i, t}+\alpha_{7} \operatorname{GROW}_{i, t}+ \\
& +\alpha_{8} \operatorname{INDFE}_{i, t}+\alpha_{9} \text { YRFE }_{i, t}+\varepsilon_{i, t} . \\
& \\
& D A_{i, t}=\alpha_{0}+\alpha_{1} \text { OUTSUB }_{i, t}+\alpha_{2} A M T_{i, t}+ \\
& +\alpha_{3} \operatorname{CINV}_{i, t}+\alpha_{4} \text { FIN }_{i, t}+\alpha_{5} F Y_{i, t}+ \\
& +\alpha_{6} \operatorname{LOSS}_{i, t}+\alpha_{7} \operatorname{GROW}_{i, t}+ \\
& +\alpha_{8} \operatorname{INDFE}_{i, t}+\alpha_{9} \text { YRFE }_{i, t}+\varepsilon_{i, t} .
\end{aligned}
$$

$D A_{i, t}$ - the difference between total discretionary accruals and non-discretionary accruals (Chin et al., 2000).

$S E O_{i, t}$ - seasoned equity offerings. Company $i$ conducts seasoned equity offerings in year $t$ equals 1 ; otherwise 0 (Chin et al., 2000).

$P I C_{i, t}$ - paid-in capital larger than NT\$ 30 million equals 1; otherwise 0 . According to Regulations GISA Firms, the financial reports should be audited by certified public accountants, if firms' paid-in capital larger than NT\$ 30 million (Chin et al., 2000).

$C P A_{i, t}$ - firm audit by certified public accountants equals 1; otherwise 0 (Dechow et al., 1996).

$B I G 4_{i, t}$ - firm audit by Big 4 accounting firms equals 1; otherwise 0 (Chin et al., 2000; Cohen \& Zarowin, 2010; Francis \& Wang, 2008; Kim et al., 2003).

OUTSUB $B_{i, t}$ - outsiders' subscription rate. The outsiders' subscription rate equals 1 minus insiders' subscription rate for company $i$ in year $t$. According to Regulations GISA Firms, the internal staffs have the right to subscribe shares before SEO information release (Brickley, Coles, \& Terry, 1994; Peasnell, Pope, \& Young, 2005).

$A M T_{i, t}$ - total fundraising amount deflated by total assets (Chin et al., 2000).

$C I N V_{i, t}$ - SEO purposes for capital investment $(C I N V)$ equals 1; otherwise 0 (Chin et al., 2000).

$S I Z E_{i, t}$ - company size. Natural logarithm of assets for companies $i$ in year $t$ (DeFond \& Park, 2001).
$F I N_{i, t}=$ SEO purposes for financial operation (FIN) equals 1; otherwise 0 (Chin et al., 2000)

$F Y_{i, t}$ - company foundation year. Natural logarithm of company $i$ in year $t$ (K. Chen, Z. Chen, \& Wei, 2009; Healy, 1985).

$\operatorname{LOSS}_{i, t}$ - an indicator variable that equals 1 if the firm is reporting a loss; otherwise 0 (Burgstahler \& Dichev, 1997).

$G R O W_{i, t}$ - growth, measured by

$$
\left(\frac{S A L E S_{i, t}-S A L E S_{i, t-1}}{S A L E S_{i, t-1}}\right)(\text { Skinner, 1993). }
$$

$L E V_{i, t}-$ debt to assets ratio for company $i$ in year $t$ (Smith \& Stulz, 1985).

YRFE - Year fixed effects. If the year 2014 equals 1, year 2015 equals 1, year 2016 equals 1, year 2017 equals 1; otherwise 0 (K. Chen, Z. Chen, \& Wei, 2009).

INDFE - GISA industry fixed effects. If the industry is electronic science and technology, cultural and creative, biotechnology medical treatment, agriculture, forestry, fishery, animal husbandry, social enterprise, e-commerce equals 1; otherwise 0 (K. Chen, Z. Chen, \& Wei, 2009).

\subsection{Sample selection}

The sample is hand-collected from the GISA Market Observation Post System of TPEx and Taiwan Economic Journal. Owing to GISA Board opened officially to the public on Jan $3^{\text {rd }}$, 2014, the research period starts in 2014. Considering the limited sample on first year of the platform, the samples for 2015 and 2016 were collected. The sample comprises a panel of 404 firm-year observations from 2014 to 2016. 206 observations were eliminated due to the lack of data on the GISA Market Observation Post System. Further, 107 observations were eliminated while this paper calculated earnings management. The final sample consists of 91 observations, including SEO and non-SEO firm-years. 
Table 2. Sample selection

\begin{tabular}{l|c}
\hline \multicolumn{1}{c|}{ Sample Selection process } & $\begin{array}{c}\text { Number of } \\
\text { observations }\end{array}$ \\
\hline Initial GISA samples from 2014 to 2016 & 404 \\
\hline $\begin{array}{l}\text { Deduct: Missing data on GISA Market } \\
\text { Observation Post System }\end{array}$ & $(206)$ \\
\hline Deduct: Missing data on earnings management & \\
measurements & $(107)$ \\
\hline Final H1 samples: & 91 \\
\hline SEO samples & 40 \\
\hline Non-SEO samples & 51 \\
\hline
\end{tabular}

Table 3. Sample by industry

\begin{tabular}{l|c:c}
\hline $\begin{array}{c}\text { By industry category (number } \\
\text { of firms) }\end{array}$ & \multicolumn{2}{|c}{ GISA firms } \\
\hline Electronic science and technology & 24 & $26 \%$ \\
\hline Cultural and creative & 19 & $21 \%$ \\
\hline Biotechnology medical treatment & 18 & $20 \%$ \\
\hline Agriculture, forestry, fishery, animal & 10 & $11 \%$ \\
husbandry & 5 & $5.5 \%$ \\
\hline Social enterprise & 5 & $5.5 \%$ \\
\hline E-commerce & 10 & $11 \%$ \\
\hline Others & 91 & $100 \%$ \\
\hline Total & & \\
\hline
\end{tabular}

\section{RESULTS AND DISCUSSION}

\subsection{Descriptive statistics}

For Table 4, the mean for discretionary accruals is 0.558 . The average SEO is 0.440 , which represents $44 \%$ of GISA firms conducting SEO. Around $63 \%$ of GISA firms have paid-in capital over NT\$ 30 million. CPAs audit half of the firms; those audited by Big 4 accounting firms are less than 35\%.

\subsection{Correlation analysis}

Table 5 reports the Pearson correlation coefficient and Spearman rank correlation coefficient between the various proxies from the data set. To examine the multi-collinearity, a case of multiple regression is used in which the predictor variables are themselves highly correlated. If the absolute value of the correlation coefficient is larger than 0.7 , two variables are highly correlated.

The correlation between DA and AMT (Total fundraising amount) are significantly correlated. By examining Variance Inflation Factor in regression equations (7), (8), and (9), the result for AMT (Total fundraising amount) is .17, 1.19, and 1.26 , respectively, which is less than 5 . This will not cause a huge impact. Also, there is a correlation between CPA and Big 4, but these two are the separate independent variables in different regressions. Thus, there is no multi-collinearity problem among the variables.

\subsection{Main results for hypotheses}

Tables 6 and 7 show the empirical results of the earnings management activities around SEO of GISA firms, examine the impact of CPAs, Big 4 accounting firms, and outsiders' subscription rate of SEO firms on earnings management.

Table 4. Descriptive statistics for GISA firms

\begin{tabular}{|c|c|c|c|c|c|c|c|}
\hline Variable & Min & P25 & P50 & P75 & Max & Mean & SD \\
\hline DA & -1.084 & 0.062 & 0.374 & 0.686 & 7.414 & 0.558 & 1.013 \\
\hline SEO & 0.000 & 0.000 & 0.000 & 1.000 & 1.000 & 0.440 & 0.499 \\
\hline CPA & 0.000 & 0.000 & 0.000 & 1.000 & 1.000 & 0.495 & 0.503 \\
\hline BIG4 & 0.000 & 0.000 & 0.000 & 1.000 & 1.000 & 0.341 & 0.477 \\
\hline PIC & 0.000 & 0.000 & 1.000 & 1.000 & 1.000 & 0.637 & 0.483 \\
\hline FY & 1.025 & 1.782 & 2.223 & 2.541 & 3.654 & 2.208 & 0.531 \\
\hline LOSS & 0.000 & 0.000 & 1.000 & 1.000 & 1.000 & 0.681 & 0.469 \\
\hline GROW & -0.806 & 0.013 & 0.348 & 0.765 & 23.796 & 0.995 & 2.970 \\
\hline LEV & -11.478 & 0.209 & 0.632 & 1.836 & 24.654 & 1.288 & 4.710 \\
\hline \multicolumn{8}{|c|}{ Observations: 91} \\
\hline
\end{tabular}

Note: $D A$, the difference between total discretionary accruals and non-discretionary accruals. SEO, seasoned equity offerings. Company, conduct SEO equals 1 ; otherwise 0 . CPA, firm audit by certified public accountants equals 1 ; otherwise 0 . BIG4, firm audit by Big 4 accounting firms equals 1 ; otherwise 0 . PIC, paid-in capital larger than NT\$30 million equals 1 ; otherwise 0 . $F Y$, company foundation year. Natural logarithm of company $i$ in year $t$. LOSS, an indicator variable that equals 1 if the firm is reporting a loss; otherwise 0 . GROW, growth, measured by the difference between sales $t$ and $t-1$ divided by sales $t-1$. LEV, leverage. Debt to assets ratio for company $i$ in year $t$. 
Table 5. Person correlation coefficient and Spearman rank correlation coefficient

\begin{tabular}{|c|c|c|c|c|c|c|c|c|c|c|c|c|}
\hline Vari & DA & CPA & BIG4 & OUTSUB & PIC & AMT & CINV & FIN & FY & LOSS & GROW & LEV \\
\hline$D A$ & 1 & -0.0261 & -0.3825 & -0.1176 & -0.2001 & 0.6430 & -0.2158 & 0.2184 & -0.3187 & 0.2590 & .0028 & 0.1069 \\
\hline CPA & .1862 & 1 & 7006 & 0.1381 & 0.2901 & 0.1306 & -0.0056 & -0.0985 & 0.1655 & -0.2576 & .1001 & 0.0784 \\
\hline$B I G 4$ & 0.2401 & 0.7267 & 1 & 0.0939 & 0.3280 & -0.1767 & -0.1301 & -0.2531 & 0.3089 & -0.1716 & .0022 & -0.2751 \\
\hline OUTS & .1999 & 57 & 344 & 1 & -0.1126 & 0.0517 & 2259 & -0.2887 & 0407 & -0.3409 & 0160 & 22 \\
\hline PIC & 0.1270 & 0.2432 & 0.3493 & 0.0000 & 1 & -0.0800 & 0.2263 & -0.2425 & 0.0601 & 0.0548 & -0.0200 & -0.3701 \\
\hline$A M T$ & & -0 & 263 & 849 & 0681 & 1 & 0.0752 & -0. & 887 & 34 & 0.1570 & \\
\hline CINV & -0.1854 & -0.0056 & -0.1301 & 0.2232 & 0.2263 & 0.0183 & 1 & -0.5253 & -0.1820 & -0 & 91 & 043 \\
\hline FIN & 1566 & -0.0985 & -0.2531 & -0.2546 & -0.2425 & 0.1021 & -0.5253 & 1 & -0.1426 & 0.4120 & 0.0849 & 0.3093 \\
\hline$F Y$ & -0.1426 & -0.0094 & 0.0417 & -0.0033 & 0.1012 & -0.1437 & -0.1834 & -0.1187 & 1 & -0.0864 & -0.4912 & 0.2275 \\
\hline LOSS & 0.3250 & -0.0783 & 0.0437 & -0.2303 & 0.0728 & 0.0635 & -0.4623 & 0.4120 & -0.1576 & 1 & -0.0699 & 0.2837 \\
\hline GROW & 0.1492 & 0.0400 & -0.0944 & 0.1513 & 0.0500 & 0.0206 & 0.3443 & 0.0999 & -0.2968 & 0.1199 & 1 & -0.0191 \\
\hline LEV & -0.0239 & 0.0957 & 0.0081 & 0.0761 & -0.0728 & -0.0096 & -0.0458 & 0.1059 & 0.0882 & 0.0439 & -0.0475 & 1 \\
\hline
\end{tabular}

Note: $D A$, the difference between total discretionary accruals and non-discretionary accruals. CPA, firm audit by certified public accountants equals 1; otherwise 0. BIG4, firm audit by Big 4 accounting firms equals 1 ; otherwise 0 . OUTSUB, the outsiders' subscription rate equals 1 minus insiders' subscription rate for company $i$ in year $t$. PIC, paid-in capital larger than NT\$ 30 million equals 1 ; otherwise 0 . AMT, total fund raising amount deflated by total assets. CINV, SEO purposes for capital investment equals 1; otherwise 0 . FIN, SEO purposes for financial operation equals 1 ; otherwise 0 . $F Y$, company foundation year. Natural logarithm of company $i$ in year $t$. LOSS, an indicator variable that equals 1 if the firm is reporting a loss; otherwise 0 . GROW, growth, measured by the difference between sales $t$ and $t-1$ divided by sales $t-1$. LEV, leverage. Debt to assets ratio for company $i$ in year $t$.

To start with, Table 6 presents the comparison of accrual-based earnings management between SEO firms and non-SEO firms listed on the GISA. For columns (1), (2), and (3), the coefficient on SEO are $0.312,0.318$, and 0.307 ( $p$-values are 0.095, 0.084, and 0.096 ), positively significant at the 0.1 level. This indicates that the SEO firms will upward discretionary accruals compared with the non-SEO firms. The coefficients on paid-in capital $(P I C)$ are $0.442,0.508$, and 0.555 , respectively ( $p$-values are $0.037,0.017$, and 0.012 ) positive related to discretionary accruals. Firms' paid-in capital larger than NT\$ 30 million tends to upward discretionary accruals. The coefficients on company size (SIZE) is -0.579 , -0.573 , and -0.563 ( $p$-value $=0.000)$, respectively, negatively related to discretionary accruals. To raise

Table 6. Main results for $H 1$ (DA and SEO)

\begin{tabular}{|c|c|c|c|c|c|c|}
\hline \multirow{2}{*}{ Variables } & \multicolumn{2}{|c|}{ (1) } & \multicolumn{2}{|c|}{$(2)$} & \multicolumn{2}{|c|}{ (3) } \\
\hline & Coefficient & $p$-value & Coefficient & $p$-value & Coefficient & $p$-value \\
\hline SEO & $0.312^{*}$ & $(0.095)$ & $0.318^{*}$ & $(0.084)$ & $0.307 *$ & $(0.096)$ \\
\hline$P I C$ & $0.442 * *$ & $(0.037)$ & $0.508 * *$ & $(0.017)$ & $0.555^{* *}$ & $(0.012)$ \\
\hline CPA & - & - & $-0.335^{*}$ & $(0.061)$ & - & - \\
\hline BIG4 & - & - & - & - & $-0.350 *$ & $(0.092)$ \\
\hline SIZE & $-0.579 * * *$ & $(0.000)$ & $-0.573 * * *$ & $(0.000)$ & $-0.563 * * *$ & $(0.000)$ \\
\hline FY & 0.154 & $(0.379)$ & 0.135 & $(0.434)$ & 0.142 & $(0.412)$ \\
\hline GROW & 0.043 & $(0.149)$ & 0.044 & $(0.131)$ & 0.037 & $(0.212)$ \\
\hline$L E V$ & -0.019 & $(0.303)$ & -0.016 & $(0.385)$ & -0.018 & $(0.318)$ \\
\hline CONSTANT & $6.184^{* * *}$ & $(0.000)$ & $6.268^{* * *}$ & $(0.000)$ & $6.107 * * *$ & $(0.000)$ \\
\hline YRFE & Yes & - & Yes & - & Yes & - \\
\hline INDFE & Yes & - & Yes & - & Yes & - \\
\hline Observations & \multicolumn{2}{|c|}{91} & \multicolumn{2}{|c|}{91} & \multicolumn{2}{|c|}{91} \\
\hline Adjusted $R^{2}$ & \multicolumn{2}{|c|}{0.403} & \multicolumn{2}{|c|}{0.422} & \multicolumn{2}{|c|}{0.417} \\
\hline $\mathrm{F}$ & $6.067^{* * *}$ & $(0.000)$ & $6.065^{* * *}$ & $(0.000)$ & $5.962 * * *$ & $(0.000)$ \\
\hline
\end{tabular}

Note: $* * *, * * *$ represent statistical significance at the $0.01,0.05$, and 0.10 levels. P-values in parentheses. DA, the difference between total discretionary accruals and non-discretionary accruals. SEO, seasoned equity offerings. Companies conduct SEO equals 1; otherwise 0 . PIC, paid-in capital larger than NT\$30 million equals 1; otherwise 0. CPA, firm audit by certified public accountants equals 1 ; otherwise 0 . BIG4, firm audit by Big 4 accounting firms equals 1 ; otherwise 0 . SIZE, company size. Natural logarithm of assets for the company $i$ in year $t$. FY, company foundation year. Natural logarithm of company $i$ in year $t$. GROW, growth, measured by the difference between sales $t$ and $t-1$ divided by sales $t-1$. LEV, leverage. Debt to assets ratio for company $i$ in year $t$. YRFE, year fixed effects. INDFE, GISA industry fixed effects. 
funds from the market or listed on the mainboard in the future, the smaller GISA firms will have upward discretionary accruals. Roychowdhury (2006) finds that the bigger GISA firms will downward discretionary accruals to minimize political costs. For column (2), the CPAs' capability in mitigating earnings management among GISA firms, including SEO and non-SEO firms, is examined. The coefficient on CPA is -0.335 ( $p$-value $=0.061$ ), negatively related to earnings management. For column (3), the Big 4 accounting firms' capability in alleviating earnings management behaviors among GISA firms is examined. The coefficient on BIG4 (firm audit by Big 4 accounting firms) is -0.350 ( $p$-value $=$ 0.092 ), negatively related to earnings management at the 0.1 level.

The previous empirical result proves that firms with SEO purposes tend to have earnings management behavior than non-SEO firms. Table 7 reports the effect of the supervision from CPAs on accrual-based earnings management. Column (4) shows that the CPAs can effectively reduce the discretionary accruals; the coefficient is -0.421 ( $p$-value $=0.072$ ), significantly negative at 0.1 level. These results also prove that public integrative counseling from CPAs had paid off and effectively reduced earnings manage- ment level. Specifically, the estimation coefficient on $A M T$ (Total fundraising amount) is 0.001 ( $p$-value = 0.000 ), significantly positive at the 0.01 level. To raise sufficient funds from the capital market, the firms would upward manipulate discretionary accruals. The coefficient on CINV (SEO purposes for capital investment) is -0.680 ( $p$-value $=0.038)$, negatively related to earnings management. Thus, SEO purposes for capital investment are not the main reason for conducting earnings management.

Column (5) shows the same results as column (4) that Big 4 accounting firms provide better earnings quality in mitigating discretionary accruals. The coefficient of BIG4 is $-0.505(p$-value $=0.020)$ significantly negative at 0.05 level. This result also proves that public integrative counseling from international accounting firms worked and effectively reduce the level of earnings management. The estimation coefficient on AMT (Total fundraising amount) is 0.001 ( $p$-value $=0.000)$, significantly positive at the 0.01 level. The firms would upward manipulate discretionary accruals to raise sufficient funds from the capital market. The coefficient on CINV (SEO purposes for capital investment $)$ is -0.856 ( $p$-value $=0.011)$, negatively related to accrual-based earnings management.

Table 7. Main results for $H 2$ ( $D A$ and external corporate governance)

\begin{tabular}{|c|c|c|c|c|c|c|}
\hline \multirow{2}{*}{ Variables } & \multicolumn{3}{|c|}{ (4) } & \multirow{2}{*}{$\frac{(5)}{p \text {-value }}$} & \multicolumn{2}{|c|}{ (6) } \\
\hline & Coefficient & $p$-value & Coefficient & & Coefficient & $p$-value \\
\hline$C P A$ & $-0.421^{*}$ & $(0.072)$ & - & - & - & - \\
\hline BIG4 & - & - & $-0.505^{* *}$ & $(0.020)$ & - & - \\
\hline OUTSUB & - & - & & - & 0.238 & $(0.360)$ \\
\hline$A M T$ & $0.001 * * *$ & $(0.000)$ & $0.001^{* * *}$ & $(0.000)$ & $0.001^{* * *}$ & $(0.000)$ \\
\hline CINV & $-0.680 * *$ & $(0.038)$ & $-0.856^{* *}$ & $(0.011)$ & $-0.640^{*}$ & (0.059) \\
\hline FIN & -0.162 & $(0.607)$ & -0.373 & $(0.242)$ & -0.099 & $(0.766)$ \\
\hline$F Y$ & 0.132 & $(0.594)$ & 0.123 & $(0.601)$ & 0.030 & $(0.907)$ \\
\hline LOSS & -0.242 & $(0.569)$ & -0.206 & $(0.604)$ & 0.076 & $(0.858)$ \\
\hline GROW & 0.012 & $(0.664)$ & 0.005 & $(0.848)$ & -0.003 & $(0.926)$ \\
\hline CONSTANT & 0.965 & $(0.239)$ & 1.121 & $(0.159)$ & 0.319 & $(0.713)$ \\
\hline YRFE & Yes & - & Yes & - & Yes & - \\
\hline INDFE & Yes & - & Yes & - & Yes & - \\
\hline Observations & \multicolumn{3}{|c|}{40} & 40 & \multicolumn{2}{|c|}{40} \\
\hline Adjusted $R^{2}$ & \multicolumn{3}{|c|}{0.803} & 0.819 & \multicolumn{2}{|c|}{0.784} \\
\hline $\mathrm{F}$ & $14.235 * * *$ & $(0.000)$ & $15.662 * * *$ & $(0.000)$ & $12.804^{* * *}$ & $(0.000)$ \\
\hline
\end{tabular}

Note: $*, * *, * * *$ represent statistical significance at the $0.01,0.05$, and 0.10 levels. $P$-values are in parentheses. $D A$, the difference between total discretionary accruals and non-discretionary accruals. CPA, firm audit by certified public accountants equals 1 ; otherwise 0 . BIG4, firm audit by Big 4 accounting firms equals 1 ; otherwise 0 . OUTSUB, outsiders' subscription rate. The outsiders' subscription rate equals 1 minus insiders' subscription rate for the company $i$ in year $t$. AMT, the total fundraising amount deflated by total assets. CINV, SEO purposes for capital investment equals 1; otherwise 0 . FIN, SEO purposes for financial operation equals 1 ; otherwise $0 . F Y$, company foundation year. Natural logarithm of company $i$ in year $t$. LOSS, an indicator variable equals 1 if the firm is reporting a loss; otherwise 0 . GROW, growth, measured by the difference between sales $t$ and $t-1$ divided by sales $t-1$. YRFE, year fixed effects. INDFE, GISA industry fixed effects. 
Column (6) shows that there is no relationship between outsiders' subscription rate and earnings management, especially in SEO firms in the GISA board, the coefficient is 0.238 ( $p$-value $=$ 0.360 ), not significant. This result reveals that either viewpoint of outsiders and earnings management has been adopted, especially for SEO firms in GISA in Taiwan. The estimation coefficient on AMT (Total fundraising amount) is 0.001 ( $p$-value $=0.000$ ), which is significantly positive at the 0.01 level, which remains the same as prior regression. The coefficient on CINV (SEO purposes for capital investment) is -0.640 ( $p$-value $=0.059)$, negatively related to earnings management.

This paper predicts the company, which is listed on GISA. Conducting SEO has a higher level of earnings management than non-SEO in $H 1$. The empirical results support $H 1$ in several ways. First, compared with non-SEO firms, the SEO firms with further SEO purposes will conduct earnings management, especially using discretionary accruals. Besides, there is a positive relationship between paid-in capital and earnings management. Firms with paid-in capital more than NT\$ 30 million tend to conduct income-increasing abnormal accruals. Moreover, due to the political costs, the larger-sized SEO firms will have downward earnings management behavior during fundraising compared with non-SEO. Last but not least, both CPAs and Big 4 serve as gatekeepers on earnings manipulation.
This paper further predicts that in SEO firms listed on GISA, the level of earnings management is lower when audited by the CPAs/ Big 4 accounting firms, and there is an association between the level of earnings management and outsiders' subscription rate in $\mathrm{H} 2 a, \mathrm{H} 2 b, \mathrm{H} 2 \mathrm{c}$. The empirical results also support $H 2 a, H 2 b$, except for $H 2 c$. Both CPAs and Big 4 accounting firms can effectively monitor the SEO firms to reduce the level of discretionary accruals. The result supports previous studies (Teoh \& Wong, 1993; Worret, 2016). This paper also finds that SEO firms with higher fundraising amounts are prone to upward accrual-based earnings management. Healy and Wahlen (1999) illustrated that capital market motivations are the most significant incentives for managers to manipulate earnings. Thus, the governance should pay more attention to the earnings management behaviors of high fundraising amounts companies.

In summary, it is found that GISA firms with the incentives of raising funds may have a counteraction of upward post-SEO performance by accrual-based earnings management. Moreover, large-sized firms are prone to decrease discretionary accruals due to political costs. Also, firms with higher fundraising amounts and paid-in capital more than NT\$ 30 million tend to have income-increasing abnormal accruals. Finally, consistent with prior literature, CPAs and Big 4 accounting firms play an important role in alleviating earnings management.

\section{CONCLUSION}

In 2014, TPEx set up a new stage, GISA, for SMEs to raise funds from the capital market, enlarge business scale and publicity, and even list on the stock market in the future. This paper examines the earnings management activities around seasoned equity offerings of GISA firms and verifies the impact of CPAs, Big 4, and outsiders on earnings management. Firms listed on the GISA not only find channels of fundraising but also look forward to listing on the mainboard and getting resources from the capital market in the future. Therefore, most of the GISA firms with SEO purposes may conduct upward earnings management, especially for accrual-based. The accruals reverse the same as previous research once the company gets sufficient funds from the capital market. Further, this paper reaches the consensus as to prior literature on earnings management incentives. To decrease political costs, large-sized companies are prone to decrease discretionary accruals. Based on capital market incentives, higher fundraising amounts will lead to an increase in accrual-based earnings management. Also, firms with paid-in capital more than NT\$ 30 million tend to have income-increasing abnormal accruals. Finally, this paper shares similar empirical results on the role of external corporate governors in mitigating earnings management and maintaining audit quality. For GISA firms in Taiwan, CPAs and Big 4 accounting firms serve as gatekeepers in alleviating earnings manipulation behaviors. As for SEO purposes, the higher the funding amounts, the higher the possibility that management may intervene in the earnings process. CPAs and Big 4 accounting firms still stand firm and remain at their posts. 
The limitation of the paper is the limited sample size. The sample size is limited because GISA set up in early January 2014 until the end of May 2017 in Taiwan. Thus, firms registered in GISA are very limited compared with the listed companies. This study implies the importance of earnings management activities for GISA firms around a specific corporate finance event, SEOs. The CPAs and Big 4 accounting firms play a key role in supervising GISA firms' corporate governance. The government can consider setting up regulations to control the corporate governance of GISA firms. GISA firms are many smallsized innovative companies with creative ideas and great potential. Because these companies may face difficulties with capital raising, company size, and proper assistance, corporate governance will be a key issue while they are growing. Future studies can apply quarterly data from GISA firms to provide more precise empirical results on the earnings management activities around SEO, further, compare the earnings management behavior between GISA and Main Board listed companies or expand research to other countries.

\section{AUTHOR CONTRIBUTIONS}

Conceptualization: Shaio Yan Huang.

Data curation: Ling-Na Chen, Wei-Hua Lin.

Formal analysis: An-An Chiu, Shaio Yan Huang, Wei-Hua Lin.

Funding acquisition: Ling-Na Chen.

Investigation: An-An Chiu, Shaio Yan Huang.

Methodology: Ling-Na Chen, Wei-Hua Lin.

Project administration: Ling-Na Chen.

Resources: Ling-Na Chen, An-An Chiu, Wei-Hua Lin.

Software: Ling-Na Chen, Wei-Hua Lin.

Supervision: An-An Chiu, Shaio Yan Huang.

Validation: Ling-Na Chen, An-An Chiu, Shaio Yan Huang.

Writing - original draft: Ling-Na Chen, An-An Chiu.

Writing - review \& editing: Ling-Na Chen, An-An Chiu, Shaio Yan Huang.

\section{REFERENCES}

1. Bédard, J., Chtourou, S. M., \& Courteau, L. (2004). The effect of audit committee expertise, independence, and activity on aggressive earnings management. Auditing: A Journal of Practice \& Theory, 23(2), 13-35. https://doi. org/10.2308/aud.2004.23.2.13

2. Brickley, J. A., Coles, J. L., \& Terry, R. L. (1994). Outside directors and the adoption of poison pills. Journal of Financial Economics, 35(3), 371-390. https://doi.org/10.1016/0304405X(94)90038-8

3. Burgstahler, D., \& Dichev, I. (1997). Earnings management to avoid earnings decreases and losses. Journal of Accounting and Economics, 24(1), 99-126. https://doi.org/10.1016/S01654101(97)00017-7
4. Chen, K. C., Chen, Z., \& Wei, K. J. (2009). Legal protection of investors, corporate governance, and the cost of equity capital. Journal of Corporate Finance, 15(3), 273-289. https://doi. org/10.1016/j.jcorpfin.2009.01.001

5. Chen, K. Y., Lin, K.-L., \& Zhou, J. (2005). Audit quality and earnings management for Taiwan IPO firms. Managerial Auditing Journal, 20(1), 86-104. https://doi. org/10.1108/02686900510570722

6. Chin, C. L., Lin, H.-W., \& Huang, S. M. (2000). Seasoned Equity Offering and Earnings Management. Sun Yat-Sen Management Review, 8(4), 709-744. Retrieved from http://mgtr.cm.nsysu.edu. tw/fulljournal_process. php?id $=56 \&$ pno $=08045 \& p=709$
7. Chung, R., Firth, M., \& Kim, J.-B. (2002). Institutional monitoring and opportunistic earnings management. Journal of Corporate Finance, 8(1), 29-48. https://doi.org/10.1016/S09291199(01)00039-6

8. Cohen, D. A., \& Zarowin, P. (2010). Accrual-based and real earnings management activities around seasoned equity offerings. Journal of Accounting and Economics, 50(1), 2-19. https://doi. org/10.1016/j.jacceco.2010.01.002

9. DeAngelo, L. E. (1986). Accounting numbers as market valuation substitutes: A study of management buyouts of public stockholders. The Accounting Review, 61(3), 400. Retrieved from https://scholar.google.com.tw/ scholar?hl=zh-TW\&as_sdt $=0 \% 2$ $\mathrm{C} 5 \& \mathrm{q}=$ Accounting + numbers $+\mathrm{as}$ 
+ market+valuation+substitutes $\%$ $3 \mathrm{~A}+\mathrm{A}+$ study + of + management $+\mathrm{b}$ uyouts+of+public+stockholders. \&btnG $=$

10. Dechow, P. M., Sloan, R. G., \& Sweeney, A. P. (1995). Detecting earnings management. The Accounting Review, 70(2), 193-225. Retrieved from https://kopernio. com/viewer?doi=10.2307/24830 3\&token $=$ WzU5MzU1OCwiMT AuMjMwNy8yNDgzMDMiXQ. p64pxLWef2mH_oRBqHwyRgBYjlo

11. Dechow, P. M., Sloan, R. G., \& Sweeney, A. P. (1996). Causes and consequences of earnings manipulation: An analysis of firms subject to enforcement actions by the SEC. Contemporary Accounting Research, 13(1), 1-36. https://doi. org/10.1111/j.1911-3846.1996. tb00489.x

12. Dechow, P., Ge, W., \& Schrand, C. (2010). Understanding earnings quality: A review of the proxies, their determinants and their consequences. Journal of Accounting and Economics, 50(2-3), 344-401. https://doi.org/10.1016/j. jacceco.2010.09.001

13. DeFond, M. L., \& Park, C. W. (2001). The reversal of abnormal accruals and the market valuation of earnings surprises. The Accounting Review, 76(3), 375404. https://doi.org/10.2308/ accr.2001.76.3.375

14. DuCharme, L. L., Malatesta, P. H., \& Sefcik, S. E. (2001). Earnings management: IPO valuation and subsequent performance. Journal of Accounting, Auditing \& Finance, 16(4), 369-396. https://doi.org/ 10.1177/0148558X0101600409

15. Fama, E. F., \& Jensen, M. C. (1983). Separation of Ownership and Control. The Journal of Law and Economics, 26(2), 301-325. http://dx.doi.org/10.1086/467037

16. Fan, Q. (2007). Earnings management and ownership retention for initial public offering firms: Theory and evidence. The Accounting Review, 82(1), 27-64. Retrieved from https://aaapubs. org/doi/abs/10.2308/accr.2007.82. 1.27? journalCode $=\mathrm{accr}$
17. Francis, J. R., \& Wang, D. (2008). The joint effect of investor protection and Big 4 audits on earnings quality around the world. Contemporary Accounting Research, 25(1), 157-191. https:// doi.org/10.1506/car.25.1.6

18. Gunny, K. A. (2005). What are the consequences of real earnings management? (Working Paper). University of Colorado. Retrieved from https://scholar.google.com. $\mathrm{tw} / \mathrm{scholar}$ ?hl=zh-TW\&as_sdt=0 $\% 2 \mathrm{C} 5 \& \mathrm{q}=$ What + are + the + conseq uences+of+real+earnings+manage ment $\% 3 F+\& b t n G=$

19. Healy, P. M. (1985). The effect of bonus schemes on accounting decisions. Journal of Accounting and Economics, 7(1-3), 85-107. Retrieved from https://scholar. google.com.tw/scholar?hl=zhTW\&as_sdt $=0 \% 2 \mathrm{C} 5 \& \mathrm{q}=$ The + effe $\mathrm{ct}+\mathrm{of}+$ bonus+schemes+on+accou nting+decisions. $+\&$ btnG $=$

20. Healy, P. M., \& Wahlen, J. M. (1999). A review of the earnings management literature and its implications for standard setting. Accounting Horizons, 13(4), 365383. https://doi.org/10.2308/ acch.1999.13.4.365

21. Jones, J. J. (1991). Earnings management during import relief investigations. Journal of Accounting Research, 29(2), 193-228. https://doi. org/10.2307/2491047

22. Kim, J. B., Chung, R., \& Firth, M. (2003). Auditor conservatism, asymmetric monitoring, and earnings management. Contemporary Accounting Research, 20(2), 323-359. Retrieved from https://onlinelibrary.wiley.com/doi/pdf/10.1506/ J29K-MRUA-0APP-YJ6V?casa token=HGRaKjBL9wUAAAAA:oIrCD9Y9vBqX648pr2QXyT WQvjNnv5tk1s8YCzdicBcWTDHZ0ElzBscnNLX7GHliXINWUaek J13ZL6GA

23. Kothari, S. P., Leone, A. J., \& Wasley, C. E. (2005). Performance matched discretionary accrual measures. Journal of Accounting and Economics, 39(1), 163-197. https://doi.org/10.1016/j.jacceco.2004.11.002
24. Peasnell, K. V., Pope, P. F., \& Young, S. (2005). Board monitoring and earnings management: do outside directors influence abnormal accruals? Journal of Business Finance \& Accounting, 32(7-8), 1311-1346. https://doi.org/10.1111/ j.0306-686X.2005.00630.x

25. Rangan, S. (1998). Earnings management and the performance of seasoned equity offerings. Journal of Financial Economics, 50(1), 101-122. https://doi.org/10.1016/S0304405X(98)00033-6

26. Roychowdhury, S. (2006). Earnings management through real activities manipulation. Journal of Accounting and Economics, 42(3), 335-370. https://doi.org/10.1016/j. jacceco.2006.01.002

27. Schipper, K. (1989). Earnings management. Accounting Horizons, 3(4), 91-102. Retrieved from https://search.proquest. com/openview/177246e104b4 3553542ab048997fla4e/1?pqorigsite $=$ gscholar $\& \mathrm{cbl}=3330$

28. Sheng, W. W. (1997). Firms' Earnings Management: An Investigation of "Accounting Policy Choices" and "Accruals". Management Review, 16(1), 11-37. Retrieved from http://www.airitilibrary.com/Publication/alDetailedMesh?DocID=10219447199701-16-1-11-37-a

29. Shivakumar, L. (2000). Do firms mislead investors by overstating earnings before seasoned equity offerings? Journal of Accounting and Economics, 29(3), 339-371. https://doi.org/10.1016/S01654101(00)00026-4

30. Skinner, D. J. (1993). The investment opportunity set and accounting procedure choice: Preliminary evidence. Journal of Accounting and Economics, 16(4), 407-445. https://doi. org/10.1016/0165-4101(93)90034D

31. Smith, C. W., \& Stulz, R. M. (1985). The determinants of firms' hedging policies. Journal of Financial and Quantitative Analysis, 20(4), 391-405. https://doi. org/10.2307/2330757 
32. Teoh, S. H., Welch, I., \& Wong, T. J. (1998). Earnings management and the long-run market performance of initial public offerings. The Journal of Finance, 53(6), 1935-1974. https://doi. org/10.1111/0022-1082.00079

33. Teoh, S. H., \& Wong, T. (1993). Perceived auditor quality and the earnings response coefficient. The Accounting Review, 68(2), 346-366. Retrieved from https://scholar. google.com.tw/scholar?hl=zhTW\&as_sdt $=0 \% 2 \mathrm{C} 5 \& \mathrm{q}=$ Perceived +auditor+quality+and+the+earnin gs+response+coefficient\&btnG=
34. Teoh, S. H., Wong, T. J., \& Rao, G. R. (1998). Are accruals during initial public offerings opportunistic? Review of Accounting Studies, 3(1-2), 175208. Retrieved from https://link. springer.com/article/10.1023 /A:1009688619882

35. Worret, D. (2016). Are 'Big Four audits' really better? - Some remarks on the 'Big Four dichotomy' in the German audit market. International Journal of Critical Accounting, 8(3-4), 246279. Retrieved from https://scholar.google.com.tw/scholar?hl=zh
TW\&as_sdt $=0 \% 2 \mathrm{C} 5 \& \mathrm{q}=$ Are $\% 2$ 7 Big+Four+audits $\% 27+$ really $+b$ etter\%3F-Some+remarks+on+th $\mathrm{e} \% 27 \mathrm{Big}+$ Four+dichotomy $\% 27 \mathrm{i}$ $\mathrm{n}+$ the + German+audit+market. \&btnG=

36. Yuk, J. H., \& Leem, W. B. (2017). The effects of the International Financial Reporting Standards (IFRS) adoption on earnings quality: evidence from Korea. Investment Management and Financial Innovations, 14(3 (contin. 1)), 243-250. Retrieved from https://www.ceeol.com/ search/article-detail?id=749344

\section{APPENDIX A}

Table A1. Variables related to earnings management

\begin{tabular}{|c|c|}
\hline Variable & Explanation \\
\hline$T A_{i, t}$ & $\begin{array}{l}\text { Total accruals in year } t \text { for company } i \\
\text { Follow Cohen and Zarowin (2010) by calculating } N I_{i, t}-C F O_{i, t} / A S S E T S_{i, t-1}\end{array}$ \\
\hline$N D A_{i, t}$ & The non-discretionary accruals for company $i$ in year $t$ \\
\hline$D A_{i, t}$ & The difference of total discretionary accruals and non-discretionary accruals for company $i$ in year $t$ \\
\hline $\operatorname{ASSETTS}_{i, t-1}$ & The total assets for company $i$ in year $t-1$ \\
\hline$S A L E S_{i, t}$ & The net sales revenue for company $i$ in year $t$ \\
\hline$\triangle S A L E S_{i, t}$ & The difference of net sales revenue for company $i$ in year $t$ and $t-1$ \\
\hline$\triangle S A L E S_{i, t-1}$ & The difference of net sales revenue for company $i$ in year $t-1$ and $t-2$ \\
\hline$\triangle R E C_{i, t}$ & The difference of account receivables for company $i$ in year $t$ and $t-1$ \\
\hline$P P E_{i, t}$ & The gross amount of fixed assets (total fixed assets minus non-depreciation fixed assets) for company $i$ in year $t$ \\
\hline$R O A_{i, t}$ & The return on assets for company $i$ in year $t$ \\
\hline
\end{tabular}


Table A2. Variables related to research model

\begin{tabular}{|c|c|c|}
\hline Variable & Explanation & Reference \\
\hline$D A_{i, t}$ & The difference between total discretionary accruals and non-discretionary accruals. & Chin et al. (2000) \\
\hline$S E O_{i, t}$ & $\begin{array}{l}\text { Seasoned equity offerings. Company } i \text { conducts seasoned equity offerings in year } t \\
\text { equals } 1 \text {; otherwise } 0 \text {. }\end{array}$ & Chin et al. (2000) \\
\hline$P I C_{i, t}$ & $\begin{array}{l}\text { Paid-in capital larger than NT\$30 million equals } 1 \text {; otherwise } 0 \text {. According to } \\
\text { Regulations GISA Firms, the financial reports should audit by certified public } \\
\text { accountants, if firms' paid-in capital larger than NT\$ } 30 \text { million. }\end{array}$ & Chin et al. (2000) \\
\hline$C P A_{i, t}$ & Firm audit by certified public accountants equals 1 ; otherwise 0. & Dechow et al. (1996) \\
\hline$B I G 4_{i, t}$ & Firm audit by Big 4 accounting firms equals 1 ; otherwise 0. & $\begin{array}{l}\text { Chin et al. (2000), Cohen and } \\
\text { Zarowin (2010), Francis and } \\
\text { Wang (2008), Kim et al. (2003) }\end{array}$ \\
\hline OUTSUB $B_{i, t}$ & $\begin{array}{l}\text { Outsiders' subscription rate. The outsiders' subscription rate equals to } 1 \text { minus } \\
\text { insiders' subscription rate for company } i \text { in year } t \text {. According to Regulations GISA } \\
\text { Firms, the internal staffs have the right to subscribe shares before SEO information } \\
\text { release. }\end{array}$ & $\begin{array}{l}\text { Brickley, Coles, and Terry (1994), } \\
\text { Peasnell, Pope, and Young } \\
\text { (2005) }\end{array}$ \\
\hline$A M T_{i, t}$ & Total fund raising amount deflated by total assets. & Chin et al. (2000) \\
\hline$C I N V_{i, t}$ & SEO purposes for capital investment (CINV) equals 1 ; otherwise 0. & Chin et al. (2000) \\
\hline$D F I N V_{i, t}$ & SEO purposes for domestic and foreign investment (DFINV) equals 1; otherwise 0. & Chin et al. (2000) \\
\hline$F I N_{i, t}$ & SEO purposes for financial operation (FIN) equals 1 ; otherwise 0. & Chin et al. (2000) \\
\hline$S I Z E_{i, t}$ & Company size. Natural logarithm of assets for company $i$ in year $t$. & DeFond and Park (2001) \\
\hline$F Y_{i, t}$ & Company foundation year. Natural logarithm of company $i$ in year $t$. & $\begin{array}{l}\text { K. Chen, Z. Chen, and Wei } \\
\text { (2009), Healy (1985) }\end{array}$ \\
\hline $\operatorname{LOSS}_{i, t}$ & An indicator variable that equals 1 if the firm is reporting a loss; otherwise 0. & Burgstahler and Dichev (1997) \\
\hline$G R O W_{i, t}$ & Growth, measured by $\left(\frac{S A L E S_{i, t}-S A L E S_{i, t-1}}{S A L E S_{i, t-1}}\right)$. & Skinner (1993) \\
\hline$L E V_{i, t}$ & Leverage. Debt to assets ratio for company $i$ in year $t$ & Smith and Stulz (1985) \\
\hline$Y R F E$ & $\begin{array}{l}\text { Year fixed effects. If the year } 2014 \text { equals } 1 \text {, year } 2015 \text { equals } 1 \text {, year } 2016 \text { equals } 1 \text {, } \\
\text { year } 2017 \text { equals } 1 \text {; otherwise } 0 .\end{array}$ & K. Chen, Z. Chen, and Wei (2009) \\
\hline$I N D F E$ & $\begin{array}{l}\text { GISA industry fixed effects. If the industry is electronic science and technology, } \\
\text { cultural and creative, biotechnology medical treatment, agriculture, forestry, } \\
\text { fishery, animal husbandry, social enterprise, e-commerce equals } 1 \text {; otherwise } 0 .\end{array}$ & K. Chen, Z. Chen, and Wei (2009) \\
\hline
\end{tabular}

